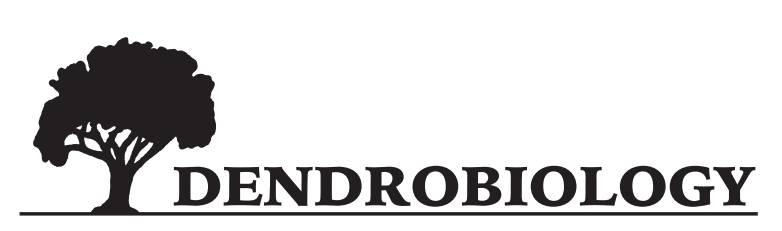

2016, vol. 76, 165-174

http://dx.doi.org/10.12657/denbio.076.016

\author{
Xinyun Xie, Jun Cui, Wentao Shi, Xijun Liu, Xiao Tao, Qin Wang, \\ Xiaoniu $X u^{*}$
}

\title{
Biomass partition and carbon storage of Cunninghamia lanceolata chronosequence plantations in Dabie Mountains in East China
}

Received: 2 February 2016; Accepted: 17 August 2016

\begin{abstract}
The quantification of biomass carbon pools is important for understanding carbon cycling in forest ecosystems. This study was designed to reveal the effects of stand age on biomass partitioning and carbon storage of Chinese fir plantation stands in Dabie Mountains of Anhui, East China. A total of six even-aged Chinese fir plantation stands along an age-sequence from 10 to 50 years were selected. To quantify the biomass of different tree components, 18 trees with diameter at breast height $\left(D_{1.3}\right)$ from 6.5 to $35.2 \mathrm{~cm}$ were harvested from the different aged stands. Biomasses of understory vegetation, forest floor and standing dead trees were also investigated. Total biomass carbon storages ranged from 57.6 to $211.4 \mathrm{Mg}$ $\mathrm{ha}^{-1}$ in the different aged stands. Tree layer comprised from $93.7 \%$ to $96.4 \%$ of the total biomass $\mathrm{C}$ pools in the different aged stands. The $\mathrm{C}$ pools of the necromass were from 1.8 to $6.2 \mathrm{Mg} \mathrm{ha}^{-1}$. Stand age had a significant effect on tree biomass partitioning, with an increase in proportion of root biomass. The root/shoot ratios were from 0.187 to 0.312 , which was significantly positively correlated to stand age. The existing plantation stands are still developing and have somewhat high rate of biomass and carbon accumulations beyond the normal rotation period (usually 25-30 years) even over an age of 50 years. Appropriate prolongation of the rotation period of Chinese fir plantation will be effective in maintaining long-term productivity and providing large carbon sink. The measurements provide valuable data for modelling productivity of Chinese fir plantation forest.
\end{abstract}

Keywords: Biomass, carbon storages, Chinese fir, plantation forest, age-sequence

Addresses: X. Xie, J. Cui, X. Liu, X. Tao, X.N. Xu, Department of Forest Science, Anhui Agricultural University, Hefei 230036, China; Collaborative Innovation Center of Agri-forestry Industry in Dabieshan Area, Hefei 230036, China, e-mail: xnxu6162@163.com or xnxu2007@ahau.edu.cn

W. Shi, Q. Wang, Department of Forest Science, Anhui Agricultural University, Hefei 230036, China, e-mail: qlsforest@ahau.edu.cn

*Corresponding author 


\section{Introduction}

Forest ecosystems play an important role in the global carbon (C) cycle, due to over $80 \%$ of the terrestrial aboveground $\mathrm{C}$ stored in forest biomass (Dixon et al., 1994; Houghton et al., 2009). The allocation pattern of plant biomass is a critical problem in ecology (Shipley \& Meziane, 2002; Weiner, 2004) and has important, practical implications from the points of view of global change and timber production. Changes in site conditions can have profound impacts on forest biomass allocation (Maherali \& DeLucia, 2001; Fan et al., 2009). Plants shift biomass allocation between their organs to respond to environmental change, which is an important mechanism to maintain productivity (Sebastià, 2007). At the community level, biomass allocation strategies are linked to the adaptive response of the forest community to site conditions (Niklas, 2005). Therefore, an accurate estimation of forest biomass is very useful for comparing structural and functional attributes of forest ecosystems across a wide range of environmental conditions (e.g. Gargaglione et al., 2010; Fernández-Martínez et al., 2014; Poorter et al., 2015).

The impact of land-use change on the $\mathrm{C}$ biogeochemical cycling has been the subject of great attention in the past two decades (e.g. Vitousek et al., 1997; Houghton, 1999; Houghton et al., 2009). Quantification of the changes in pool size and fluxes of $\mathrm{C}$ and nutrients is fundamental to the understanding of the effects of land-use change and forest management on ecosystem functioning. In addition, pool size and fluxes of $\mathrm{C}$ and nutrients in forests vary considerably because of climatic, edaphic and topographic differences, and vary with the land use history and anthropogenic and natural disturbances as well. Although there is a large dataset about the forest biomass relating only to aboveground biomass, the information is still largely missing about root biomass (Noguchi et al., 2007). Roots are an important component of ecosystem dynamics and function in forests (Matamala et al., 2003; Noguchi et al., 2007; Jagodziński \& Kałucka, 2011). Therefore, inventories of pools and fluxes should be as complete as possible, but often only parts of ecosystems are investigated.

Chinese fir (Cunninghamia lanceolata (Lamb.) Hook) is one of the most important native tree species in subtropical China and plays an important role in the global $\mathrm{C}$ cycle because its plantation area is over 12 million ha, accounting for $24 \%$ of the total plantations in China (Lei, 2005) and about $4.5 \%$ of all plantation forests in the world (FAO, 2010). Chinese fir is also the most commonly used commercial species for industrial timber production in China. Its wood is used for home construction, furniture, ship-building, and so on. The great silvicultural and ecological variability exists among Chinese fir stands because of its wide-spread distribution and over thousand-year cultivation (Feng et al., 1984). As a result, the biomass production of Chinese fir plantation varied greatly on various growing regions and in different elevations (Pan et al., 1983; Feng et al., 1984), and at different growth stages (Chen, 1998).

In this study, an investigation was conducted on biomass $\mathrm{C}$ storage at both above- and below-ground in a chronosequence of Chinese fir plantations in the northernmost distribution region. We hypothesized that the biomass accumulation and $\mathrm{C}$ storage at both above- and below-ground components increased with stand ages and had a greater allocation to the belowground in comparison to the aboveground. The objectives of this study were (1) to quantify $\mathrm{C}$ accumulation in tree biomass of Chinese fir chronosequence stands, (2) to examine the dependence upon age of the above- and below-ground $\mathrm{C}$ pool in this plantation forest, and (3) to provide new data about the growth and productivity of Chinese fir stands in the northern edge of its natural distribution.

\section{Materials and methods}

\section{Study site}

This study was conducted at the National Mazongling Forestry Farm in western Anhui, East China $\left(31^{\circ} 16^{\prime} \mathrm{N}, 115^{\circ} 45^{\prime} \mathrm{E}\right)$. The climate of the region is humid continental with warm, humid summers and cool, dry winters. The annual precipitation averages $1480 \mathrm{~mm}$, distributed mostly from April to August. Annual mean temperature is approximately $14.6^{\circ} \mathrm{C}$.

The study area is a mountainous landscape (elevation 450-1790 $\mathrm{m}$ a.s.1.) with steep convex slopes. The predominant lithology is composed of granite. Upland soils are relatively shallow $(70-100 \mathrm{~cm}$ depth) mountainous yellow soils. They are loam in texture with $\mathrm{pH}\left(\mathrm{H}_{2} \mathrm{O}\right)$ of 4.3-5.5.

The vegetation in the study area is dominated by secondary deciduous broad-leaved forest on lower slope (below $600 \mathrm{~m}$ elevation), deciduous broadleaved and coniferous mixed forest on mid-slope (600-1200 m), and coniferous forest on the upper slope (above $1200 \mathrm{~m}$ ). There are large plantation forests particularly Chinese fir and Huangshan mountain pine (Pinus taiwanensis Hayata) plantations on mid-slope at elevation between $500 \mathrm{~m}$ and $1200 \mathrm{~m}$ in this forestry farm. The plantation forests are composed of over $40 \%$ of the total forest area. In July 2013 and 2014, the representative Chinese fir chronosequence plantations $(10,22,36,45,48$, and 50 years old) at elevation between $800 \mathrm{~m}$ and $1150 \mathrm{~m}$ were selected for the study. The area of plantations for each age ranged from 1.3 to 8.2 ha, and no fer- 
Table 1. Characteristics of the sampling stands of Chinese fir plantations in Dabie Mountains in Anhui, East China ( \pm S.E.; $\mathrm{n}=3$ )

\begin{tabular}{ccccccc}
\hline Stand age $(\mathrm{yr})$ & Mean $D_{\mathrm{l}_{3}}(\mathrm{~cm})$ & Mean height $(\mathrm{m})$ & Stand density $\left(\right.$ stems ha $\left.{ }^{-1}\right)$ & Elevation $(\mathrm{m}$ a.s.l.) & Inclination $\left(^{\circ}\right)$ & Soil depth $(\mathrm{cm})$ \\
\hline 10 & $12.3 \pm 1.9$ & $8.1 \pm 0.6$ & $2875 \pm 173$ & 800 & 22 & $>100$ \\
22 & $14.1 \pm 1.4$ & $11.1 \pm 1.2$ & $2086 \pm 87$ & 1050 & 35 & 90 \\
36 & $21.4 \pm 1.5$ & $14.3 \pm 0.9$ & $1475 \pm 83$ & 970 & 36 & 85 \\
45 & $24.1 \pm 1.7$ & $15.7 \pm 1.5$ & $1128 \pm 49$ & 860 & 30 & 85 \\
48 & $25.9 \pm 2.1$ & $16.1 \pm 1.3$ & $1350 \pm 51$ & 835 & 32 & 95 \\
50 & $27.3 \pm 1.7$ & $16.9 \pm 0.8$ & $1075 \pm 52$ & 1140 & 35 & 90 \\
\hline
\end{tabular}

tilization was applied. All the stands were the first rotation. Three plots $(20 \mathrm{~m} \times 20 \mathrm{~m}$ in size $)$ were randomly established within each stand (Table 1). All the sampling plots were less than $1.0 \mathrm{~km}$ apart. Tree height $(H)$ and diameter at breast height $\left(D_{1.3}\right)$ were measured for all trees within these plots.

\section{Biomass estimation}

In order to quantify the biomass of different tree components (foliage, branch, stem-bark, stem-wood and root), we harvested 18 trees of Chinese fir with $D_{13}$ values ranging from 6.5 to $35.2 \mathrm{~cm}$ from the different aged stands. Three trees were sampled for each stand including mean $D_{1.3}$, the minimum and maximum $D_{1.3}$ class. If there was ony one tree in this $D_{1.3}$ class, the sampling tree was selected from the adjacent next $D_{1.3}$ class. The stem of each sampling tree was cut in 2-m sections and weighed freshly. A disk was cut from the stump, and the top and middle of each stem section for determination of moisture content, bark/wood ratio, and specific gravity. The dry weights of the bark and wood for each section were calculated from the bark/wood ratios, the field fresh weights, and the moisture contents.

All branches were cut from the sample tree. All foliage and current twigs were clipped from the branches and weighed in the field, and subsamples were taken for moisture determination. The root biomass of individual trees was determined through excavation where a cylinder extending from the ground projection of the crown downward the depth where no coarse root appeared was used as a means to ascertain the data. Although it is understood that a certain percentage of roots may grow beyond the diameter of the projected crown, roots that overlap with other tree roots could offset remote roots outside the projected area. Soil was carefully excavated and passed through a wire sieve (about 20-mm mesh) where roots were then collected. Stumps and attached taproots were pulled out. Any soil residue that remained on the roots was removed by washing and brushing. In this way, partial small and fine roots with diameter less than $5 \mathrm{~mm}$ was not included the root biomass.

On the basis of these data, the independent variables included $D_{1.3}, H, D_{1.3} H, D_{1.3}^{2}$, and $D_{1.3}{ }^{2} H$, whereas the dependent variable was dry mass of each component (stems, branches, leaves, and coarse roots). In this study, transformed and untransformed data were evaluated for model development to reduce the residual heteroscedasticity (Parresol, 1999). Several allometric relationships between independent and dependent variables were tested. Model comparison and selection were based on coefficients of determination $\left(\mathrm{R}^{2}\right)$ and squared residuals (Sokal \& Rohlf, 1981; Parresol, 1999). The models using only $D_{1.3}$ as a single independent variable were found to be the best-fit for estimations of component biomass and total biomass with the exception for foliar biomass. All of the optimal regression models were statistically highly significant $(p<0.01)$ (Table 2$)$. Stem diameter explained a large percent of the variation in the dry mass. The detailed description of biomass model development was given by Xie (2015) .

Three mechanic random $2 \mathrm{~m} \times 2 \mathrm{~m}$ subplots sampled above- and below-ground biomass for the understory (shrubs with $D_{1.3}<3.0 \mathrm{~cm}$ and herbs) in each plot. All plants with a $D_{1.3}$ less than $3.0 \mathrm{~cm}$ rooted in the subplot were clipped and their roots were excavated. All materials weighed fresh. The subsamples were taken for moisture determination.

Necromass or dead plant material found at ground level was divided into fine necromass (litter and woody material $<2 \mathrm{~cm}$ in diameter) and large necromass (dead woody material $\geq 2 \mathrm{~cm}$ in diameter). Large necromass was evaluated from one $5 \mathrm{~m} \times 5 \mathrm{~m}$ subplots in the center of each sampling plot, while fine necromass was estimated from four $0.5 \mathrm{~m} \times 0.5$ $m$ quadrats (grouping these into one sample for analysis) in the four corners of each subplot. The subsamples were taken for moisture determination.

Plant tissue samples (stem wood, stem bark, live branch, twig, foliage, root and necromass) collected were oven-dried at $70^{\circ} \mathrm{C}$ to the constant weight, and then ground with a laboratory mill. The ground samples were preserved for chemical analysis.

\section{Carbon concentration and pool}

For each sampling tree, three samples representative of each component (stem wood, stem bark, branch, foliage, and root) were selected for analysis of $\mathrm{C}$ concentration. The samples of stem wood and 
bark were selected from a disk cut from the base, middle and top of the stem section. The root samples were selected from large root $(\mathrm{d}>5 \mathrm{~cm})$, middle root $(2 \mathrm{~cm} \leq \mathrm{d} \leq 5 \mathrm{~cm})$ and small root $(\mathrm{d}<2 \mathrm{~cm})$. The samples of branch and foliage were selected from the low, middle and up crown. The all plant samples with three replicates were analysed for concentrations of total organic $\mathrm{C}$ using the induction furnace method with a EA $3000 \mathrm{CHN} / \mathrm{O}$ Analyzer (Vector, Italy). The $\mathrm{C}$ pool in the biomass of each stand were calculated by multiplying the mean $\mathrm{C}$ concentration in each component by its respective dry mass.

\section{Statistical analysis}

Stand age was the treatment used in the analyses of variance (ANOVAs): (1) one simple ANOVA using age as factor and fine necromass, and the percentage of the biomass components as variables, respectively, (2) one simple ANOVA using age as factor and the C concentration of Chinese fir components as variable. Differences among the means of the fine necromass, biomass percentage and $\mathrm{C}$ concentration were determined with a Tukey's HSD test at a significance level of $p<0.05$. Before the ANOVAs, the data were checked for normality and homogeneity of variances and were ln-transformed to correct for deviations from these assumptions when needed. All statisti- cal analyses were performed using STATISTICA 7.0 (StatSoft Inc.) for Windows.

\section{Results}

\section{Stand characteristics}

The stand characteristic parameters for the sampling stands of Chinese fir are given in Table 1 . The canopy heights ranged from $8.1 \mathrm{~m}$ of 10-year-old young stand to $16.9 \mathrm{~m}$ of 50 -year-old matured stand. Stand tree density declined with stand age, while tree height and mean $D_{1.3}$ increased with stand age (Table 1). The undergrowth including shrubs and herbs was not well-developed in all of the sampling stands particularly for the young and mid-aged stands.

\section{Stand biomass}

Using the equations from Table 2, the above- and below-ground biomass were estimated (Table 3 ). The total biomass (overstory + understory) was from $114.15 \mathrm{Mg} \mathrm{ha}^{-1}$ for the 10 -year-old stand to 396.42 $\mathrm{Mg} \mathrm{ha}^{-1}$ for the 48-year-old stand. The overstory biomass was significantly correlated with stand age (Fig. 1 ). The proportion of understory biomass to total biomass ranged from $0.51 \%$ for the 10 -year-old stand to

Table 2. Biomass optimal equations for Chinese fir plantation in Dabie Mountains in Anhui, East China $(\mathrm{n}=18)$. All allometric equations were statistically significant at $p<0.01$. Abbreviations: $D_{1.3}(\mathrm{~cm})$ - diameter at breast height; W $(\mathrm{kg})$ - tree dry biomass; SSR - sum of squared residuals

\begin{tabular}{|c|c|c|c|}
\hline Biomass component & Optimal equation & $\mathrm{R}^{2}$ & SSR \\
\hline Foliage & $\mathrm{W}=2.26+0.004 D_{1.3}{ }^{2}+0.00001809 D_{1.3}{ }^{4}$ & $0.915^{* *}$ & 93.138 \\
\hline Branch & $\mathrm{W}=0.023 D_{1.3}^{2.282}$ & $0.871^{* *}$ & 2.703 \\
\hline Stem & $\mathrm{W}=0.026 D_{1.3}^{2.704}$ & $0.984^{* *}$ & 0.424 \\
\hline Root & $\mathrm{W}=0.002 D_{1.3}^{3.200}$ & $0.933^{* *}$ & 2.441 \\
\hline Total & $\mathrm{W}=0.050 D_{1.3}^{2.686}$ & $0.975^{* *}$ & 0.648 \\
\hline
\end{tabular}

** $-\mathrm{p}<0.01$.

Table 3. Standing biomass $\left(\mathrm{Mg} \mathrm{ha}^{-1}\right)$ and biomass allocation (\%) in different components of the different aged stands of Cunninghamia lanceolata in Dabie Mountains in Anhui, east China

\begin{tabular}{|c|c|c|c|c|c|c|c|c|c|}
\hline \multirow[b]{2}{*}{$\begin{array}{c}\text { Stand age } \\
(\mathrm{yr})\end{array}$} & \multicolumn{5}{|c|}{ Overstory } & \multicolumn{3}{|c|}{ Understory } & \multirow[b]{2}{*}{ Total } \\
\hline & Foliage & Branch & Stem & Root & Sub-total & $\begin{array}{l}\text { Above } \\
\text { ground }\end{array}$ & $\begin{array}{l}\text { Below } \\
\text { ground }\end{array}$ & Sub-total & \\
\hline 10 & $\begin{array}{c}9.42 \\
(8.30 a)\end{array}$ & $\begin{array}{c}20.30 \\
(17.87 a)\end{array}$ & $\begin{array}{c}66.18 \\
(58.26)\end{array}$ & $\begin{array}{c}17.67 \\
(15.56 a)\end{array}$ & $113.57(100)$ & $0.27(46.6)$ & $\begin{array}{c}0.31 \\
(53.4)\end{array}$ & $0.58(100)$ & 114.15 \\
\hline 22 & $\begin{array}{c}7.86 \\
(6.70 b)\end{array}$ & $\begin{array}{c}20.11 \\
(17.15 a)\end{array}$ & $\begin{array}{c}69.43 \\
(59.23)\end{array}$ & $\begin{array}{c}19.84 \\
(16.92 \mathrm{a})\end{array}$ & $117.24(100)$ & $0.64(54.7)$ & $\begin{array}{c}0.53 \\
(45.3)\end{array}$ & $1.17(100)$ & 118.41 \\
\hline 36 & $\begin{array}{c}10.77 \\
(4.97 c)\end{array}$ & $\begin{array}{c}33.29 \\
(15.36 b)\end{array}$ & $\begin{array}{c}128.93 \\
(59.49)\end{array}$ & $\begin{array}{c}43.74 \\
(20.18 b)\end{array}$ & $216.73(100)$ & $1.13(52.6 b)$ & $\begin{array}{c}1.02 \\
(47.4)\end{array}$ & $2.15(100)$ & 218.88 \\
\hline 45 & $\begin{array}{c}12.02 \\
(4.48 c)\end{array}$ & $\begin{array}{c}36.87 \\
(13.76 c)\end{array}$ & $\begin{array}{l}159.62 \\
(59.55)\end{array}$ & $\begin{array}{c}59.52 \\
(22.21 c)\end{array}$ & $268.03(100)$ & $1.55(57.2)$ & $\begin{array}{c}1.16 \\
(42.8)\end{array}$ & $2.71(100)$ & 270.74 \\
\hline 48 & $\begin{array}{c}17.66 \\
(4.50 c)\end{array}$ & $\begin{array}{c}52.14 \\
(13.29 \mathrm{c})\end{array}$ & $\begin{array}{l}232.74 \\
(59.30)\end{array}$ & $\begin{array}{c}89.93 \\
(22.91 \mathrm{~cd})\end{array}$ & 392.47 (100) & $2.56(64.8)$ & $\begin{array}{c}1.39 \\
(35.2)\end{array}$ & $3.95(100)$ & 396.42 \\
\hline 50 & $\begin{array}{c}16.44 \\
(4.54 c)\end{array}$ & $\begin{array}{c}46.83 \\
(12.95 c)\end{array}$ & $\begin{array}{l}213.68 \\
(59.08)\end{array}$ & $\begin{array}{c}84.75 \\
(23.43 \mathrm{~d})\end{array}$ & $361.70(100)$ & $3.23(65.8)$ & $\begin{array}{c}1.68 \\
(34.2)\end{array}$ & $4.91(100)$ & 366.61 \\
\hline
\end{tabular}

Values in the parentheses are percentages of the sub-total biomass. Percentages with the same letter within a column are not significantly different at the $p<0.05$ levels. 

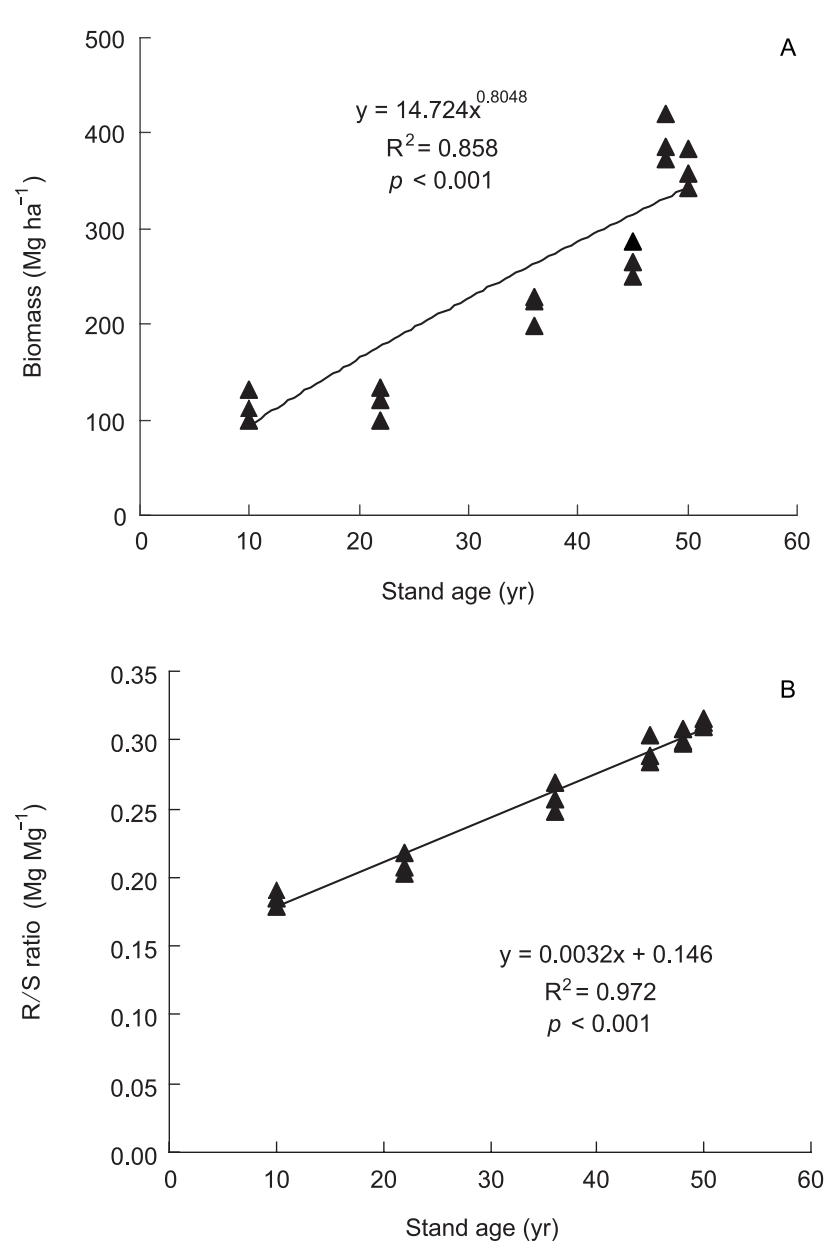

Fig. 1. Relationships between overstory total biomass (A) and $\mathrm{R} / \mathrm{S}$ ratio (B) and stand age for Cunninghamia lanceolata plantations in Dabie Mountains in Anhui, East China

$1.34 \%$ for the 50 -year-old stand, and increased with stand age. Biomass of overstory vegetation was distributed for the young and mid-aged stands (10 and 22 years old) as follows: stem $>$ branch $>$ root $>$ foliage, while for the mature stands ( $\geq 36$-year-old) as stem $>$ root $>$ branch $>$ foliage. Proportion of roots (overstory + understory) to total biomass was ranged from $15.8 \%$ (10-year-old) to $23.6 \%$ (50-year-old), which indicated the importance of roots in biomass

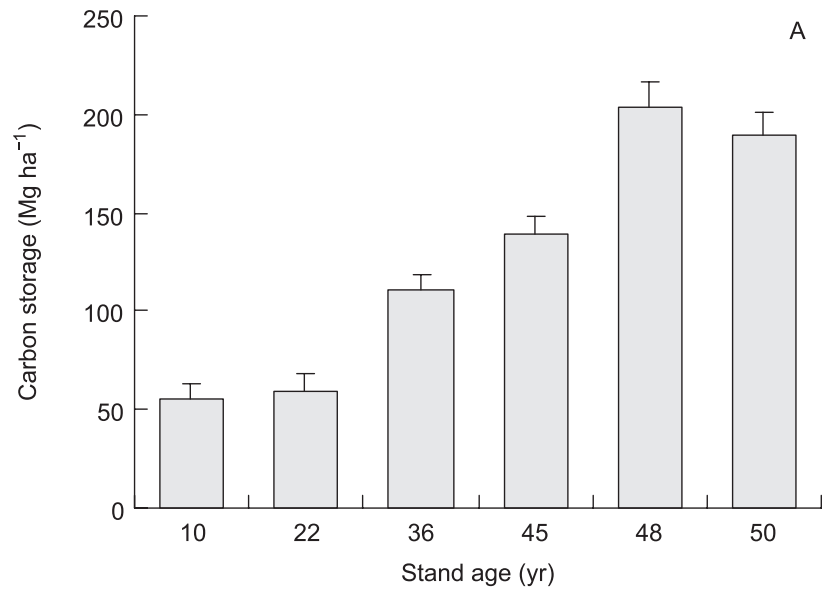

$\square$ Overstory

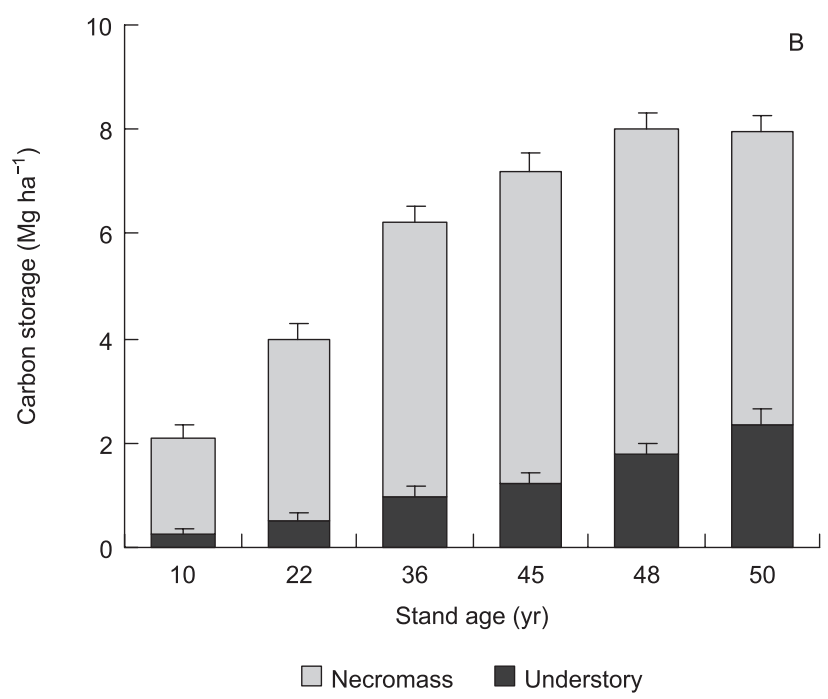

Fig. 2. Biomass $C$ storages in overstory (A), understory and necromass (B) in the different aged stands of Cunninghamia lanceolata in Dabie Mountains in Anhui, East China. Necromass included the standing dead trees, fine and large necromasses. Error bars indicate the standard error of the mean $(n=3)$

estimation for the forest stand. Proportion of foliage to total biomass was much greater in the young than in mature stand (Table 3 ). The root/shoot ratios were from 0.19 to 0.31 , and appeared significant and positive correlation to stand age (Fig. 1).

Table 4. Biomass of forest floor and standing dead trees $\left(\mathrm{Mg} \mathrm{ha}^{-1}\right)$ in the different aged stands of Cunninghamia lanceolata in Dabie Mountains in Anhui, east China

\begin{tabular}{|c|c|c|c|c|}
\hline Stand age (yr) & Fine necromass & Large necromass & Standing dead trees & Total \\
\hline 10 & $3.72(0.57) \mathrm{a}$ & na & na & $3.72 \mathrm{a}$ \\
\hline 22 & $6.93(1.15) b$ & na & na & $6.93 \mathrm{~b}$ \\
\hline 36 & $10.36(1.78) c$ & na & $0.23(0.27)$ & $10.59 \mathrm{c}$ \\
\hline 45 & $11.79(1.93) \mathrm{d}$ & na & na & $11.79 \mathrm{C}$ \\
\hline 48 & $12.35(2.01) \mathrm{d}$ & $0.17(0.22)$ & $0.15(0.19)$ & $12.67 \mathrm{c}$ \\
\hline 50 & $11.28(1.61) \mathrm{cd}$ & $0.33(0.25)$ & na & $11.61 \mathrm{c}$ \\
\hline
\end{tabular}

Values are means with SE in the parentheses and those with the same letter are not significantly different at the $p<0.05$ levels. na, not appeared. 
Table 5. Mean C concentrations $\left(\mathrm{g} \mathrm{kg}^{-1}\right)$ with SE in the parentheses of different biomass components in the different aged stands of Cunninghamia lanceolata in Dabie Mountains in Anhui, East China

\begin{tabular}{|c|c|c|c|c|c|c|c|c|c|c|}
\hline \multirow{2}{*}{$\begin{array}{l}\text { Stand } \\
\text { age (yr) }\end{array}$} & \multicolumn{4}{|c|}{ Overstory } & \multicolumn{3}{|c|}{ Understory } & \multicolumn{3}{|c|}{ Necromass } \\
\hline & Foliage & Branch & Stem & Root & Foliage & $\begin{array}{l}\text { Stem and } \\
\text { branch }\end{array}$ & Root & $\begin{array}{l}\text { Standing } \\
\text { dead trees }\end{array}$ & Fine & Large \\
\hline 10 & $\begin{array}{c}502.19 \\
(3.23) \mathrm{aC}\end{array}$ & $\begin{array}{c}473.72 \\
(3.82) \mathrm{aB}\end{array}$ & $\begin{array}{c}496.91 \\
(1.76) \mathrm{aC}\end{array}$ & $\begin{array}{c}466.38 \\
(1.35) \mathrm{aA}\end{array}$ & $\begin{array}{c}457.53 \\
(2.76) \mathrm{aB}\end{array}$ & $\begin{array}{c}471.46 \\
(2.07) \mathrm{aC}\end{array}$ & $\begin{array}{c}406.35 \\
(2.46) \mathrm{aA}\end{array}$ & & $\begin{array}{l}496.26 \\
(3.74) b c\end{array}$ & \\
\hline 22 & $\begin{array}{c}503.68 \\
(3.51) \mathrm{aB}\end{array}$ & $\begin{array}{c}505.92 \\
(2.97) \mathrm{bcB}\end{array}$ & $\begin{array}{c}514.37 \\
(2.29) \mathrm{abC}\end{array}$ & $\begin{array}{c}483.77 \\
(2.26) \mathrm{bA}\end{array}$ & $\begin{array}{c}470.04 \\
(2.65) \mathrm{bcB}\end{array}$ & $\begin{array}{c}481.93 \\
(3.15) \mathrm{bC}\end{array}$ & $\begin{array}{c}412.52 \\
(2.53) \mathrm{bA}\end{array}$ & & $\begin{array}{l}499.04 \\
(3.92) \mathrm{c}\end{array}$ & \\
\hline 36 & $\begin{array}{c}508.73 \\
(2.97) \mathrm{abB}\end{array}$ & $\begin{array}{c}510.29 \\
(1.86) \mathrm{cB}\end{array}$ & $\begin{array}{c}516.53 \\
(1.69) \mathrm{bcB}\end{array}$ & $\begin{array}{c}493.84 \\
(2.18) \mathrm{cA}\end{array}$ & $\begin{array}{c}476.71 \\
(2.16) \mathrm{bB}\end{array}$ & $\begin{array}{c}483.47 \\
(2.77) \mathrm{bB}\end{array}$ & $\begin{array}{c}420.29 \\
(2.38) \mathrm{cA}\end{array}$ & $\begin{array}{c}511.73 \\
(3.49) \mathrm{BC}\end{array}$ & $\begin{array}{c}491.48 \\
(4.23) \mathrm{bA}\end{array}$ & $\begin{array}{c}506.73 \\
(3.16) \mathrm{bB}\end{array}$ \\
\hline 45 & $\begin{array}{c}514.76 \\
(2.77) \mathrm{bA}\end{array}$ & $\begin{array}{c}508.04 \\
(2.56) \mathrm{bcA}\end{array}$ & $\begin{array}{l}521.86 \\
(1.19) \mathrm{cB}\end{array}$ & $\begin{array}{c}519.41 \\
(2.59) \mathrm{dAB}\end{array}$ & $\begin{array}{c}469.63 \\
(2.23) \mathrm{cB}\end{array}$ & $\begin{array}{c}481.64 \\
(2.63) \mathrm{bC}\end{array}$ & $\begin{array}{c}423.58 \\
(2.18) \mathrm{cA}\end{array}$ & & $\begin{array}{c}490.62 \\
(4.57) \mathrm{b}\end{array}$ & $\begin{array}{c}497.56 \\
(3.62) \mathrm{a}\end{array}$ \\
\hline 48 & $\begin{array}{c}506.36 \\
(2.51) \mathrm{abA}\end{array}$ & $\begin{array}{c}502.41 \\
(2.90) \mathrm{bA}\end{array}$ & $\begin{array}{c}522.83 \\
(1.63) \mathrm{cB}\end{array}$ & $\begin{array}{c}518.54 \\
(2.48) \mathrm{dB}\end{array}$ & $\begin{array}{c}476.79 \\
(1.97) \mathrm{bC}\end{array}$ & $\begin{array}{c}453.53 \\
(3.11) \mathrm{cB}\end{array}$ & $\begin{array}{c}437.49 \\
(2.54) \mathrm{dA}\end{array}$ & $\begin{array}{c}513.92 \\
(3.37) \mathrm{B}\end{array}$ & $\begin{array}{c}488.75 \\
(4.82) \mathrm{bA}\end{array}$ & $\begin{array}{c}493.73 \\
(3.55) \mathrm{aA}\end{array}$ \\
\hline 50 & $\begin{array}{c}517.28 \\
(2.63) \mathrm{bA}\end{array}$ & $\begin{array}{c}517.27 \\
(3.34) \mathrm{dA}\end{array}$ & $\begin{array}{c}526.23 \\
(1.67) \mathrm{cdB}\end{array}$ & $\begin{array}{c}524.01 \\
(2.43) \mathrm{dAB}\end{array}$ & $\begin{array}{c}486.38 \\
(2.74) \mathrm{dB}\end{array}$ & $\begin{array}{c}492.81 \\
(3.37) \mathrm{dB}\end{array}$ & $\begin{array}{c}451.64 \\
(2.73) \mathrm{eA}\end{array}$ & & $\begin{array}{c}481.77 \\
(4.39) \mathrm{aA}\end{array}$ & $\begin{array}{c}495.46 \\
(3.64) \mathrm{aB}\end{array}$ \\
\hline
\end{tabular}

Different letters (a-d within a column; A-C within a line) indicate significant difference for the different types (overstory, understory, and necromass) at the $p<0.05$ probability level.

\section{Mass of forest floor and standing dead trees}

Litter on the forest floor mainly consisted of newly fallen twigs with leaves and fragmented litter. Forest floor dry mass ranged from 3.72 to $12.35 \mathrm{Mg} \mathrm{ha}^{-1}$ for the sampling stands (Table 4). It was constant as stand became mature (over 45-year-old).

The standing dead trees were only appeared in both 36- and 48-year-old stands. Large necromass appeared only in 48- and 50-year-old stands. Their necromasses were very low with $0.17-0.33 \mathrm{Mg} \mathrm{ha}^{-1}$ for the large necromass and $0.15-0.23 \mathrm{Mg} \mathrm{ha}^{-1}$ for the standing dead trees (Table 4).

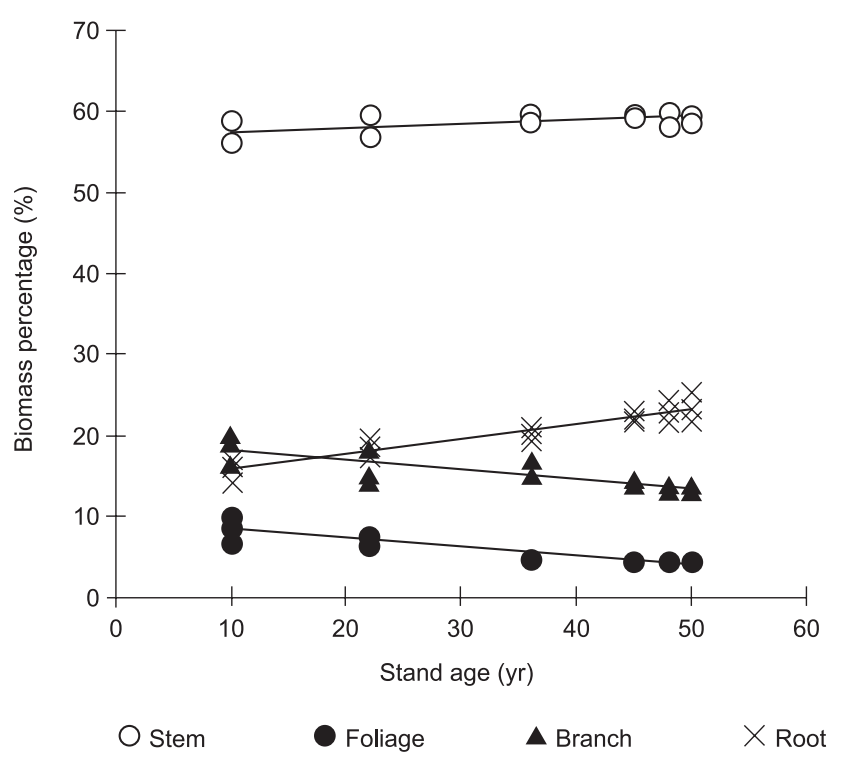

Fig. 3. Effect of stand age on biomass allocation (percentages of stem, branches, foliage, and root to the total standing biomass, respectively)

\section{Biomass carbon pool}

The C concentrations did not vary greatly among the overstory biomass components and necromass of the different aged stands (Table 5). The C concentrations of components ranged from 466.4 to 526.2 $\mathrm{g} \mathrm{kg}^{-1}$ for the overstory trees and necromass, which were higher than the understory vegetation ranging from 406.4 to $492.8 \mathrm{~g} \mathrm{~kg}^{-1}$.

Total biomass C pools ranged from 57.6 to 211.4 $\mathrm{Mg} \mathrm{ha}^{-1}$ in the different aged stands (Fig. 2). Tree layer comprised from $93.7 \%$ to $96.4 \%$ of the total biomass $\mathrm{C}$ pools in the different aged stands. The $\mathrm{C}$ pools of the necromass were from 1.8 to $6.2 \mathrm{Mg} \mathrm{ha}^{-1}$.

\section{Discussion}

\section{Biomass accumulation in relation to stand age}

In this chronosequence study, our results suggest a significant effect of stand age on standing tree biomass and its partitioning. We found an increase in proportion of root biomass along with a decrease in foliage and branch biomass while the proportion of stem biomass to total biomass remained constant (Table 3). Our findings are in agreement with previous studies conducted by Zhong et al. (2008) in Chinese fir (Cunninghamia lanceolata) plantations and by Cao et al. (2012) in Chinese pine (Pinus tabulaeformis) forests and Li et al. (2011) in Korean pine (Pinus koraiensis) plantations. However, some other studies showed the different results. Yu et al. (2013) observed an increase in the stem biomass partitioning along with a decrease in branches and foliage 
biomass partitioning for Chinese fir plantations in southwestern China. Jagodziński et al. (2014) also showed an increase in woody biomass partitioning along with a decrease in foliage biomass partitioning for Scots pine (Pinus sylvestris) stands. Those results suggest that tree biomass partitioning is not only controlled by stand age but other factors, such as stand density (Zhang et al., 2012) and site condition (Unger et al., 2012), also have an important effect on tree biomass partitioning. Due to our sampling stands located in the northernmost limit of Chinese fir distribution and in relatively high elevation, low air temperature and loose loam-textured soil could be the major factors controlling biomass partitioning, particularly for a high proportion of root biomass in this study. Up to day, there is still a lack of allometric data for belowground root biomass despite of a large body of data for aboveground tree biomass of Chinese fir (Huang et al., 2016). Therefore, it is imperative to improve the estimation of tree root biomass since belowground root biomass may account for a significant portion of total forest biomass and provide an additional important $\mathrm{C}$ pool (Cairns et al., 1997; Peichl \& Arain, 2006).

The root/shoot ratios $(\mathrm{R} / \mathrm{S})$ calculated in this study were from 0.187 to 0.312 for the different aged stands (10- to 50-year-old). The R/S ratios in this forest were high compared to the values reported for the same tree plantations in Guangxi (0.135-0.145 for stands over 6-50-year-old) by Yu et al. (2013) and in Fujian (0.173-0.246 for stands over 40-87-yearold) by Zhong et al. (2008). The R/S ratios of our sites were lower than the average global value of 0.34 for tropical deciduous forest (Jackson et al., 1996). In this study, the small and fine-root ( $<5 \mathrm{~mm}$ diameter) was not included in belowground biomass, which resulted in a relatively low $\mathrm{R} / \mathrm{S}$ ratio in this plantation forest. The relatively high $\mathrm{R} / \mathrm{S}$ ratio at our site could be attributive to several abiotic factors. The high elevation results in low temperature which is probable a cause of increased allocation to root (Lambers et al., 2008). Water and nutrient availability may be another factor affecting biomass allocation (Poorter et al., 2012). Our site characterised by steep slope and high precipitation with a dry season in autumn and early winter, which can cause nutrient leaching and water loss. Therefore, low availabilities of nutrients and water might be important factors for increasing biomass allocation to root.

In this study, total live biomass of Chinese fir plantations ranged from 114.2 (10-year-old) to $396.4 \mathrm{Mg}$ ha $^{-1}$ (48-year-old), of which the overstory biomass was from 113.6 to $392.5 \mathrm{Mg} \mathrm{ha}^{-1}$. The values obtained in this study were within the ranges of overstory biomass (49.3-644.1 $\mathrm{Mg} \mathrm{ha}^{-1}$ ) for nation-wide Chinese fir plantations of 5- to 63-year-old (Feng et al., 1999). Cheng et al. (2013) reported the total over- story live biomass ranged from 329.3 to $646.5 \mathrm{Mg}$ ha $^{-1}$ in 37-95-year-old Japanese cedar (Cryptomeria japonica (L. f.) D. Don) stands in central Taiwan. For 20-46-year-old plantations of evergreen broad-leaved species (including Michelia macclurei Dandy, Schima superba Gardn. et Champ., Cinnamomum camphora (L.) Presl.) in eastern China, total biomass values were from 116.3 to $264.2 \mathrm{Mg} \mathrm{ha}^{-1}$ (Feng et al., 1999). In global reviews by Martínez-Yrízar (1995) and Murphy and Lugo (1986), the aboveground biomass of tropical dry forests ranged from approximately 23 to $273 \mathrm{Mg} \mathrm{ha}^{-1}$. These comparisons indicate that the Chinese fir plantations appear capable of maintaining relatively high rates of biomass accumulation.

\section{Biomass C pool}

The $\mathrm{C}$ concentrations were significantly different between tree components and between stand ages for the same component $(p<0.05)$. On average, the highest $\mathrm{C}$ concentration was showed in the wood of tree while the lowest in the root of understory vegetation. Zhong et al. (2008) showed the similar trend of $\mathrm{C}$ concentrations in mature and old-growth stands of Chinese fir. However, Li (2010) determined the C concentrations of the leaves, branch, stem, and root of the same tree species as 534.3, 511.1, 509.4, and $491.8 \mathrm{~g} \mathrm{~kg}^{-1}$, respectively. The $\mathrm{C}$ concentrations in biomass components may be affected by the stand age, plant species, and pedo-climatic conditions (Bert \& Danjon, 2006).

The total biomass (including necromass) $\mathrm{C}$ storages in Chinese fir chronosequence plantations ranged from 57.6 to $211.4 \mathrm{Mg} \mathrm{ha}^{-1}$. The $\mathrm{C}$ storages in understory vegetation and coarse necromass showed a clear age-related pattern in this study. However, C storages in fine necromass (forest floor) leveled off 36 years after establishment, which was in agreement with the results reported by Shutou and $\mathrm{Na}$ kane (2004) and Chen et al. (2013) for Japanese cedar plantations. Because $\mathrm{C}$ pool in forest floor may stabilize at steady-state level in late stages of stand development, most $\mathrm{C}$ sequestration occurs in the live tree biomass C (Shutou \& Nakane, 2004; Jandl et al., 2007). The variations of $C$ pools in understory vegetation were dependent on stand density, forest management and soil conditions, which can affect light and nutrient availability particularly for the development of understory vegetation (Peichl \& Arain, 2006). The $C$ pools of the coarse necromass appeared a great heterogeneity among the stands. The variations were controlled by forest management activities and disturbances (Woodall et al., 2013).

The annual mean values of the overstory biomass $\mathrm{C}$ increments for the Chinese fir plantations in Dabie Mountains ranged from 2.70 to $5.55 \mathrm{Mg} \mathrm{C} \mathrm{ha}^{-1} \mathrm{yr}^{-1}$. Those values were within the range of $2.36-6.71 \mathrm{Mg}$ 
$\mathrm{C} \mathrm{ha} \mathrm{yr}^{-1}$ for this plantation forest nationwide (Feng et al., 1999). This result suggests that the Chinese fir plantation in Dabie Mountains has a relatively high rate of biomass $\mathrm{C}$ accumulation.

In addition to the increase in tree biomass $\mathrm{C}$ storages, the average stand $D_{1.3}$ significantly increased with age (Table 1). At our site, the annual mean $C$ increment in stem wood and coarse root of the Chinese fir plantations in 36-50-year-old were 3.27 and $1.63 \mathrm{Mg} \mathrm{ha}^{-1} \mathrm{yr}^{-1}$, respectively. This indicates that a large portion of accumulated $\mathrm{C}$ can be allocated into long-lived stem wood and coarse root, which is probably involved in the increase of stand productivity and $\mathrm{C}$ sequestration potential at the mature stages (Tian et al., 2011). At present, the rotation of Chinese fir plantation is usually $25-30$ years. Therefore, appropriate prolongation of the rotation of Chinese fir plantation can be a good practice to benefit timber production and to provide a great $\mathrm{C}$ sink of this plantation forest.

\section{Conclusion}

Our results showed a significant effect of stand age on standing biomass and biomass partitioning, and confirmed our hypothesis that the Chinese fir plantations at the high elevation in Dabie Mountains had a relatively greater biomass allocation to the belowground. The consideration of stand-age effect can provide more accurate estimates of forest biomass and $\mathrm{C}$ sequestration potential. The Chinese fir is one of the most important tree species for commercial timber production with a relatively short rotation (usually 25-30 years) management in China. The findings from this study indicate that the present Chinese fir plantations have somewhat high rate of biomass accumulation beyond the normal rotation period even over an age of 50 years. Consequently, appropriate prolongation of the rotation period will be effective in maintaining long-term site productivity and providing large sink for atmospheric $\mathrm{CO}_{2}$.

\section{Acknowledgement}

We are very grateful for Dr. A.M. Jagodzinski and two anonymous reviewers for their constructive comments and suggestions. This project was financially supported by the National Key Basic Research Program of China (No. 2012CB416905), National Natural Science Foundation of China (NSFC, No. 31370626). We greatly acknowledge the National Mazongling Forestry Farm for the use of their Chinese fir stands and providing us with the information of forest management activities. We are thankful to Mrs. L. Zhang, C. Zhang, J. Yang, J. Xu, L.L. Zhu and Z.L. Ding for sample collection and/or laborato- ry analysis. Prof. C. Song at the University of North Carolina reviewed the draft and gave valuable comments.

\section{References}

Bert D \& Danjon F (2006) Carbon concentration variations in the roots, stem and crown of mature Pinus pinaster (Ait.). Forest Ecology and Management 222: 279-295.

Cairns MA, Brown S, Helmer EH \& Baumgardner GA (1997) Root biomass allocation in the world's upland forests. Oecologia 111: 1-11.

Cao J, Wang X, Tian Y, Wen Z \& Zha T (2012) Pattern of carbon allocation across three different stages of stand development of a Chinese pine (Pinus tabulaeformis) forest. Ecological Research 27: 883-892.

Chen H (1998) Biomass and nutrient distribution in a Chinese-fir plantation chronosequence in Southwest Hunan, China. Forest Ecology and Management 105: 209-216.

Cheng CH., Hung CY, Chen CP \& Pei CW (2013) Biomass carbon accumulation in aging Japanese cedar plantations in Xitou, central Taiwan. Botanical Studies 54: 60.

Dixon RK, Solomon AM, Brown S, Houghton RA, Trexier MC \& Wisniewski J (1994) Carbon pools and flux of global forest ecosystems. Science 263 : 185-190.

Fernández-Martínez M, Vicca S, Janssens IA, Luyssaert S, Campioli M, Sardans J, Estiarte M \& Peñuelas J (2014) Spatial variability and controls over biomass stocks, carbon fluxes, and resource-use efficiencies across forest ecosystems. Trees 28: 597-611.

FAO (2010) Global forest resources assessment 2010. Main report. FAO Forestry Paper: 163.

Fan JW, Wang K, Harris W, Zhong HP, Hu ZM, Han B, Zhang WY \& Wang JB (2009) Allocation of vegetation biomass across a climate-related gradient in the grasslands of Inner Mongolia. Journal of Arid Environments 73: 521-528.

Feng ZW, Chen CY, Zhang JW, Zhao JL, Wang KP \& Zeng SY (1984) Biological productivity of Chinese fir stands at different distribution zones. Acta Phytoecologica et Geobotanica Sinica 8: 93-100.

Feng ZW, Wang XK \& Wu G (1999) Biomass and productivity of forest ecosystem in China. China Science Press, Beijing.

Gargaglione V, Peri PL \& Rubio G (2010) Allometric relations for biomass partitioning of Nothofagus antarctica trees of different crown classes over a site quality gradient. Forest Ecology and Management 259: 1118-1126. 
Houghton RA (1999) The annual net flux of carbon to the atmosphere from changes in land use 1850-1990. Tellus 51B: 298-313.

Houghton RA, Hall F \& Goetz SJ (2009) Importance of biomass in the global carbon cycle. Journal of Geophysical Research 114: 1-13.

Huang XZ, Xu CH, Xu J, Tao X \& Xu XN (2016) Structural equation model analysis of the relationship between environmental and stand factors and net primary productivity in Cunninghamia lanceolata plantations. Acta Ecologica Sinica. (in press)

Jackson RB, Canadell J, Ehleringer JR, Mooney HA, Sala OE \& Schulze ED (1996) A global analysis of root distributions for terrestrial biomes. Oecologia 108: 389-411.

Jagodziński AM, Kałucka I, Horodecki P \& Oleksyn J (2014) Aboveground biomass allocation and accumulation in a chronosequence of young Pinus sylvestris stands growing on a lignite mine spoil heap. Dendrobiology 72: 139-150.

Jagodziński AM \& Kałucka I (2011) Fine root biomass and morphology in an age-sequence of post-agricultural Pinus sylvestris stands. Dendrobiology 66: 71-84.

Jandl R, Lindner M, Vesterdal L, Bauwens B, Bartiz R, Hagedorn F, Johnson DW, Minkkinen K \& Byrne KA (2007) How strongly can forest management influence soil carbon sequestration? Geoderma 137: 253-268.

Lambers H, Chapin III FS \& Pons TL (2008) Plant physiological ecology. Springer.

Lei JF (2005) Forest resources of China. Chinese Forestry Publication House, Beijing, pp. 172-173.

Li X, Yi MJ, Son Y, Park PS, Lee KH, Son YM, Kim RH \& Jeong MJ (2011) Biomass and Carbon Storage in an Age-Sequence of Korean pine (Pinus koraiensis) Plantation Forests in Central Korea. Journal of Plant Biology 54: 33-42.

Li Y (2010) Carbon storage of Cunninghamia lanceolata mature plantation in Shaowu, Fujiang Province. Ph.D. dissertation. Chinese Academy of Forestry, Beijing, China.

Maherali H \& DeLucia EH (2001) Influence of climate-driven shifts in biomass allocation on water transport and storage in ponderosa pine. Oecologia 129: 481-491.

Martínez-Yrízar A (1995) Biomass distribution and primary productivity of tropical dry forests: Seasonally dry tropical forests (ed. by SH Bullock, HA Mooney \& E Medina) Cambridge University Press, Cambridge, pp. 326-345.

Matamala R, Gonzalez-Meler MA, Jastrow JD, Norby RJ \& Schlesinger WH (2003) Impacts of fine root turnover on forest NPP and soil C sequestration potential. Science 302: 1385-1387.
Murphy PG \& Lugo AE (1986) Structure and biomass of a subtropical dry forest in Puerto Rico. Biotropica 18: 89-96.

Niklas KJ (2005) Modelling below- and above-ground biomass for non-woody and woody plants. Annals of Botany 95: 315-321.

Noguchi K, Konôpka B, Satomura T, Kaneko S \& Takahashi M (2007) Biomass and production of fine roots in Japanese forests. Journal of Forest Research 12: 83-95.

Pan W, Tian D, Lei Z \& Kang W (1983) Studies on nutrient cycling in Chinese fir plantations in hilly region. II. Contents, accumulation rates and biological cycling of nutrient elements. Journal of Central South Forestry University 3: 1-17.

Parresol BR (1999) Assessing tree and stand biomass: a review with examples and critical comparisons. Forest Science 45: 573-593.

Peichl M \& Afrain MA (2006) Above- and belowground ecosystem biomass and carbon pools in an age-sequence of temperate pine plantation forests. Agricultural and Forest Meteorology 140: 51-63.

Poorter H, Jagodzinski AM, Ruiz-Peinado R, Kuyah S, Luo Y, Oleksyn J, Usoltsev VA, Buckley TN, Reich PB \& Sack L (2015) How does biomass distribution change with size and differ among species? An analysis for 1200 plant species from five continents. New Phytologist 208: 736-749.

Poorter H, Niklas KJ, Reich PB, Oleksyn J, Poot P \& Mommer L (2012) Biomass allocation to leaves, stems and roots: meta-analyses of interspecific variation and environmental control. New Phytologist 193: 30-50.

Sebastià MT (2007) Plant guilds drive biomass response to global warming and water availability in subalpine grassland. Journal of Applied Ecology 44: 158-167.

Shipley B \& Meziane D (2002) The balanced-growth hypothesis and the allometry of leaf and root biomass allocation. Functional Ecology 16: 326-331.

Shutou K \& Nakane K (2004) Change in soil carbon cycling for stand development of Japanese cedar (Cryptomeria japonica) plantations following clear-cutting. Ecological Research 19: 233-244.

Sokal RR \& Rohlf FJ (1981) Biometry. The principles and practice statistics in biological research. W.H. Freeman, San Francisco.

Tian D, Xiang W, Chen X, Yan W, Fang X, Kang W, Dan X, Peng C \& Peng Y (2011) A long-term evaluation of biomass production in first and second rotations of Chinese fir plantations at the same site. Forestry 84: 411-418.

Unger M, Homeier J \& Leuschner C (2012) Effects of soil chemistry on tropical forest biomass and productivity at different elevations in the equatorial Andes. Oecologia 170: 263-274. 
Vitousek PM, Aber JD, Howarth RW, Likens GE, Matson PA, Schindler DW, Schlesinger WH \& Tilman DG (1997) Human alteration of the global nitrogen cycle: sources and consequences. Ecological Applications 7: 737-750.

Weiner J (2004) Allocation, plasticity and allometry in plants. Perspectives in Plant Ecology Evolution and Systematics 6: 207-215.

Woodall CW, Walters BF, Oswalt SN, Domke GM, Toney C \& Gray AN (2013) Biomass and carbon attributes of downed woody materials in forests of the United States. Forest Ecology and Management 305: 48-59.

Xie XY (2015) Characteristics of Productivity and C and N Dynamics of Chinese Fir Plantation. Ph.D.
Dissertation. Anhui Agricultural University, Hefei, China.

Yu YF, Song TQ, Zeng FP, Peng WX, Wen YG, Huang CB, Wu QB, Zeng ZX \& Yu Y (2013) Dynamic changes of biomass and its allocation in Cunninghamia lanceolata plantations of different stand ages. Chinese Journal of Ecology 32: 1660-1666.

Zhang WP, Jia XE, Morris EC, Bai YY \& Wang GX (2012) Stem, branch and leaf biomass-density relationships in forest communities. Ecological Research 27: 819-825.

Zhong XF, Yang YS, Gao R, Xie JS, Yang ZJ \& Liu LZ (2008) Carbon storage and allocation in oldgrowth Cunninghamia lanceolata plantation in subtropical China. Journal of Subtropical Resources and Environment 3: 11-18. 